\title{
Colonization of an empty island: how does a plant with a plastic gender system respond?
}

\author{
M. Philipp and H. Adsersen \\ Department of Biology, University of Copenhagen, Universitetsparken 15, 2100 Copenhagen $\varnothing$, Denmark \\ Correspondence to: M. Philipp (marianp@bio.ku.dk)
}

Received: 10 April 2014 - Published in Biogeosciences Discuss.: 11 July 2014

Revised: 3 October 2014 - Accepted: 7 October 2014 - Published: 3 December 2014

\begin{abstract}
Honckenya peploides is the most common plant species on the island of Surtsey. It arrived in 1967 and after a juvenile period of 4 years it produced seeds and had increased its number from below 100 to several millions. Most populations had the individuals distributed in a regular or random pattern, suggesting that intraspecific competition is important. H. peploides has a subdioecious reproductive system consisting of pistillate plants producing capsules, and staminate plants delivering pollen. Some of the latter are in addition producing capsules and are denoted hermaphrodites. Populations at the south coast of Iceland had around equal numbers of pistillate and staminate plants. At Surtsey we found more pistillate plants, probably due to their higher water stress tolerance. We also found a tendency to a higher frequency of hermaphrodite plants with a higher number of seeds per capsule compared to populations at the south coast of Iceland and the nearby island of Heimaey. We suggest that this arises from the time right after the colonization of Surtsey where population size was small and the small generalist pollinators were not able to deposit sufficient pollen on pistillate plants, causing the hermaphrodites to have an advantage by being able to set seed after selfing. The result of this initial advantage of the hermaphrodites in combination with the inheritance of the sexes can still be seen due to the longevity of individuals. A generalized account of the colonization history of $H$. peploides is given.
\end{abstract}

\section{Introduction}

Surtsey is the youngest and southernmost island in the Vestmannaeyjar Archipelago south of Iceland. It appeared as a result of volcanic eruptions during the years 1963 to 1967.
The barren volcanic surface of the island was soon colonized by plants dispersed as seeds by sea water (Fridriksson, 1989). The new environment was in many respects different from where the plants came from: the substrate was recent volcanic tephra or lava with very low contents of $\mathrm{C}$ and $\mathrm{N}$, and there were no or very few competitors, herbivores or pollinators. This would favour or constrain other phenotypes and genotypes than in the source population, and the isolation would reduce gene flux from the latter. The results may be differences in genetic diversity, morphology and/or reproductive system as compared to the source populations.

Plants that successfully colonize isolated localities are supposed to possess reproductive systems able to function in spite of low density of mates or pollinators (Baker, 1955). Many reproductive systems studied at oceanic islands have turned out to be "mixed mating systems" able to produce seeds after selfing as well as out-crossing (Barrett, 1989; Bramow et al., 2013; Philipp et al., 2006). Such a system implies reproductive assurance and maintains the potential for generating individuals with different adaptive properties.

In the present paper, we focus on the reproductive system of Honckenya peploides (L.) Ehrh. (Caryophyllaceae) and how it responded after establishment on Surtsey where, initially, there were no or very few pollinators and few mates.

H. peploides has a circumpolar distribution and is fairly common on sandy beaches throughout the distribution area. Populations occur on many beaches of Iceland where individuals form large clumps by vegetative propagation. The immigration history of $H$. peploides on Surtsey is well known. The first individuals were recorded in 1967 (Fridriksson and Johnsen, 1968). In 1968, 103 individuals were observed and during 1968 to 1972 the number of recorded individuals was between 52 and 71 (Fridriksson, 1992). The 


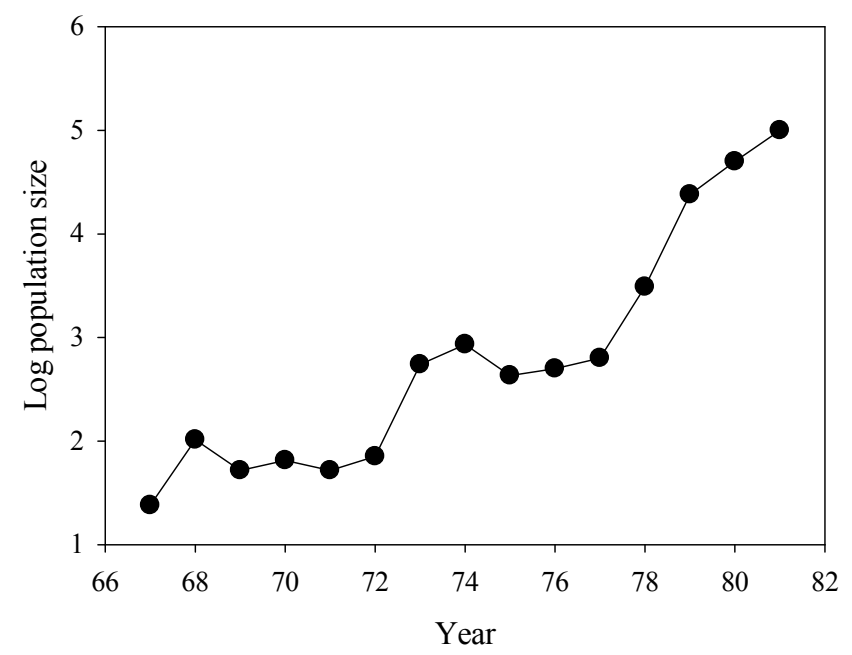

Figure 1. Increase in number of Honckenya peploides plants on Surtsey between the years 1967 and 1981 (after Fridriksson, 1992).

first capsule was observed in 1971 (Fridriksson, 1982), and in 1973 the number of recorded individuals increased to $>500$. This indicated that in the first years the population was building up from immigrating seeds and that the founding population size was $\sim 100$ individuals. The abrupt increase in 1973 must have been due to successful seed set and local dispersal episodes in 1972. From then $H$. peploides spread rapidly all over the island from the coast to the top of the two calderas (ca. $150 \mathrm{~m}$ a.s.l.) and it is at present the most common plant species with probably millions of individuals (Fridriksson, 1992) (Figs. 1 and 2). Throughout the 1970s all colonizing individuals were marked with sticks on which a number and the year of the first observation were noted. Most of the marker sticks are still extant so it is possible to age many individuals, and of course none are more than 50 years old.

In most populations of $H$. peploides two types of flowers (pistillate or staminate) occur (see below and Fig. 3). Plants with pistillate flowers do not have functional stamens and most often develop copious capsules whereas the staminate plants have stamens and no or in some cases few capsules. The reproductive system may be characterized as subdioecious as the staminate plants function as males, mostly. Crossing experiments in a Greenlandic population showed that the staminate plants were self-compatible (Eithun, 2003) as was also found in H.p. subsp. major from Japan (Tsukui and Sugawara, 1992).

During the initial colonization in 1967-1972, H. peploides survived with very few and scattered individuals (Figs. 1 and 2) (Fridriksson, 1992; Jakobsson et al., 2007). Given that the staminate $H$. peploides individuals are able to set seeds after selfing, we expected the reproductive system to have responded in the direction of a higher degree of hermaphroditism. In populations with large distances among individuals and with few pollinators, successful seed set may occur more frequently in hermaphrodites than in pistillate individuals.

By comparing populations at Surtsey with populations on the Icelandic mainland and Heimaey, we address the following questions:

1. Has the sexual reproductive system of $H$. peploides changed from subdioecy towards hermaphroditism?

2. Has the ratio between pistillate and staminate individuals in populations influenced the male and female function of the individuals?

3. Has population age or stability any influence on the ratio between pistillate and staminate individuals?

4. Which mechanisms could be involved in such changes?

\section{The species}

Sea sandwort, Honckenya peploides (L.) Ehrh. (Caryophyllaceae) has been subdivided into four varieties, of which $H$. peploides var. diffusa (Horn.) Mattf. (Böcher et al., 1978) is the arctic circumpolar variety that occurs in Iceland. $H$. peploides is a perennial hemicryptophyte and shoots sprout each spring from buds on prostrate rhizomes forming dense clones. The leaves are opposite and succulent with short internodes. The clones are found on beaches as pioneers and often become covered by sand. A unique feature of the $H$. peploides populations at Surtsey is that most of them have established and developed without interspecific competition and disturbance by human activities. As a result of this most individuals consist of rounded pillows or mats up to $6 \mathrm{~m}$ in diameter and consequently, we had no problem in identifying single individuals. In mainland situations, individuals tend to become fragmented due to disturbance, competition and senescence, so it was harder to identify individuals and avoid resampling of genets. The amplified fragment length polymorphism (AFLP) analyses of the collected material show, however, that no genetically identical individuals were recorded in our samplings (K. Anamthawat-Jónsson, personal communication, 2014). Flowers are white and solitary in leaf axils. Two types of flowers are found (Fig. 3). On some individuals the flowers possess short petals, nonfunctional anthers and long styles (pistillate). These individuals are producing plenty of globular capsules with large seeds. On other individuals the petals are longer, anthers are well-developed and the styles are short (staminate). These individuals function mainly as males but some, in addition, are able to produce a few capsules with seeds and are denoted hermaphrodites (Eithun, 2003; Malling, 1957; Sánchez-Vilas et al., 2010; Tsukui and Sugawara, 1992). 

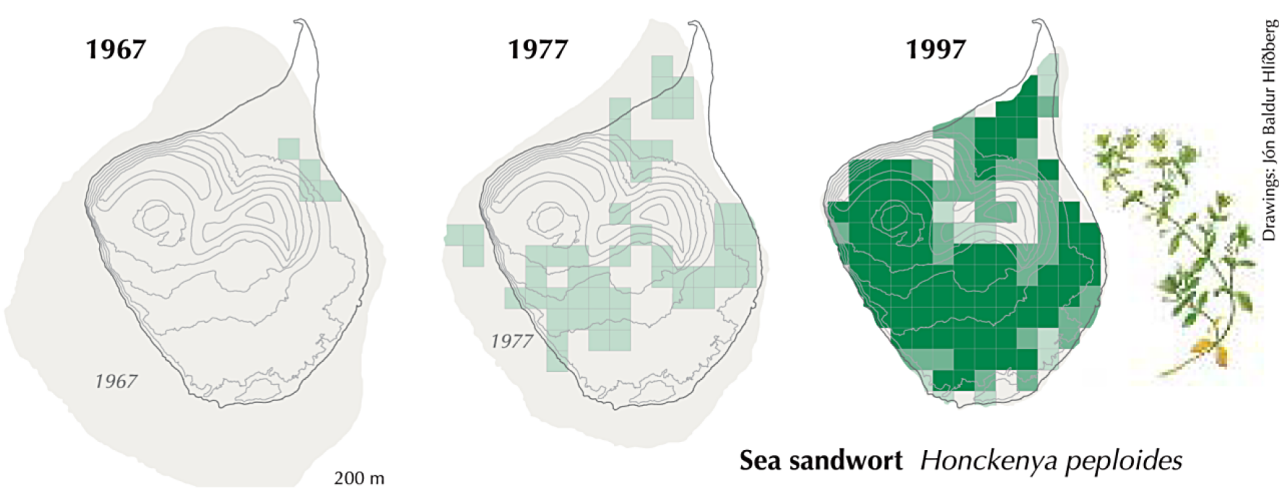

Figure 2. During 1967 to 1997 Honckenya peploides dispersed to every part of Surtsey. The shaded areas indicate the shape of the island in the respective years. The intensity of green reflects the abundance of the plant (Jakobsson et al., 2007).

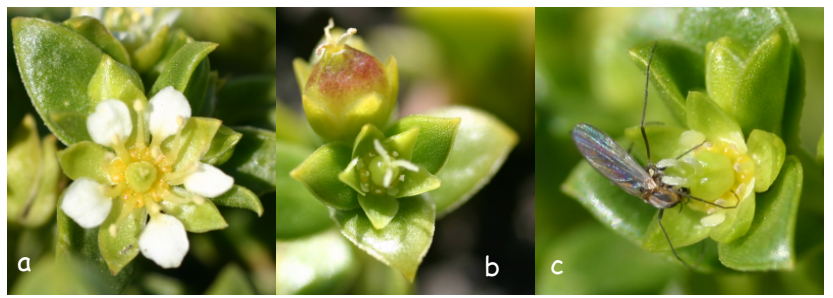

Figure 3. Honckenya peploides: (a) staminate flower, (b) pistillate flower and a capsule, (c) pistillate flower visited by Halocladius variabilis.

\section{Methods}

During the summer of 2010 we spent a few days at Surtsey. As the colonization and spread of the plants has been followed closely (Fridriksson, 2000; Magnússon et al., 2009) we were able to select populations on Surtsey to represent various ages and degrees of disturbance. We sampled from the cohorts 1973 and 1977 plus from five populations on Surtsey, and additionally from two populations on the largest island of the Vestmannaeyjar Archipelago, Heimaey, and two at the south coast of the mainland of Iceland (Table 1). The non-Surtsey samples are in the following denoted: HI. In each population, we selected a central point and recorded flowering plants within a circle including at least 30 individuals. We mapped the individuals and noted the morph of the plants (morph ratio) and collected flowers and capsules from 15 pistillate (female function) and 15 staminate (male and female function) individuals. If fewer than 15 of one morph were found within the circle, we supplemented with plants outside the circle. In some areas, the seedling density was also assessed. This procedure made it possible to estimate population densities, and distances between individuals. By recording the density in concentric circle rings of equal area, and in angular octants, we were able to assess dispersion pattern (variance to mean ratio and $\chi^{2}$ test). These population characteristics are summarized in Table 1 . We also recorded the minimum distance from each individual to its neighbour and from each individual to an individual of the same and opposite morph respectively.

The collected flowers and capsules were stored in $50 \%$ ethanol for later inspection. In the lab one non-dehisced anther from up to four individuals per population was placed in glycerol on an object glass and finely subdivided. All pollen grains were counted and the diameter of 20 pollen grains was measured under a microscope with the software: Nikon NIS Elements 3.2. In a subsample of 300 pollen grains per individual we counted what we considered functioning (good) and non-functioning ( $b a d$ ) pollen. The good pollen grains were large and circular whereas the bad grains were smaller and often shrivelled. All seeds and unfertilized ovules were counted from mostly three capsules from each individual.

\section{Results}

\subsection{Dispersion of individuals}

Dispersion of individuals in the Surtsey populations turned out to be regular to random, except for one population where the substratum was a semi-circular belt beneath a slope. In the only population where we measured the areas of each individual the pistillate plants were significantly larger than the staminate ones $(t$ test, $p<0.001)$. We calculated for all the populations the mean of distances from each individual to its neighbour (mean min distance in Table 1). We also calculated mean min distance from each individual to one of the same or the different morph but found no coherent pattern.

\subsection{Morph ratios}

Morph ratios (i.e. percentage of pistillate plants) varied from 46 to $84 \%$ (Table 1) and were significantly different from equality between pistillate and staminate plants ( $G$ test, $p<0.001)$ across populations studied on Surtsey. We subdivided the populations at Surtsey into three categories: old, 
Table 1. Honckenya peploides sample properties. S - samples from Surtsey, H - samples from Heimaey, I - samples from mainland Iceland. Names are the same as in Árnarson et al. (2014). Individuals are flowering individuals. Longest diameter (m) is double the distance from the farthest individual to the sample centre. Min. distance $(\mathrm{m})$ is the distance from an individual to its nearest flowering neighbour. $P$ ratio is the proportion of pistillate individuals in the sample. For the populations HA, HB and IG the sample areas were of irregular shape or fragmented, so it was not possible to obtain reliable measures of density or distance between individuals.

\begin{tabular}{|c|c|c|c|c|c|c|c|c|c|c|}
\hline $\begin{array}{l}\text { Sample } \\
\text { name }\end{array}$ & Characteristic & $\begin{array}{l}\text { Date of } \\
\text { sampling }\end{array}$ & $\begin{array}{r}\mathrm{N}- \\
\text { position }\end{array}$ & $\begin{array}{r}\text { E- } \\
\text { position }\end{array}$ & $\begin{array}{l}\text { Longest } \\
\text { diameter }\end{array}$ & $\begin{array}{r}\text { No. of } \\
\text { individuals }\end{array}$ & $\begin{array}{r}\text { Adult } \\
\text { density } \\
m^{-2}\end{array}$ & $\begin{array}{r}\text { Mean } \\
\text { min } \\
\text { distance }\end{array}$ & $\begin{array}{r}P \\
\text { ratio }\end{array}$ & $\begin{array}{r}\text { Juvenile } \\
\text { density }\end{array}$ \\
\hline SE & intermediate age & $13 \mathrm{Jul}$ & $63^{\circ} 18.192^{\prime}$ & $20^{\circ} 35.637^{\prime}$ & 22 & 51 & 0.134 & 1.02 & 0.49 & 5.74 \\
\hline SK & old, slope & $15 \mathrm{Jul}$ & $63^{\circ} 18.405^{\prime}$ & $20^{\circ} 36.214^{\prime}$ & 94 & 30 & 0.0043 & 5.05 & 0.68 & \\
\hline SC & old & $13 \mathrm{Jul}$ & $63^{\circ} 18.246^{\prime}$ & $20^{\circ} 36.751^{\prime}$ & 24 & 35 & 0.077 & 1.25 & 0.46 & 1.43 \\
\hline SD & young & $14 \mathrm{Jul}$ & $63^{\circ} 18.500^{\prime}$ & $20^{\circ} 35.987^{\prime}$ & 22 & 71 & 0.187 & 1.25 & 0.53 & 0.76 \\
\hline SF & old, competition & $15 \mathrm{Jul}$ & $63^{\circ} 17.942^{\prime}$ & $20^{\circ} 36.348^{\prime}$ & 19.5 & 29 & 0.097 & 3.5 & 0.84 & \\
\hline Cohorts & only dated plants & $13 \mathrm{Jul}$ & $63^{\circ} 18.246^{\prime}$ & $20^{\circ} 36.751^{\prime}$ & 420 & 27 & 0.000195 & 26.3 & 0.59 & \\
\hline HA & beach & 9 Jul & $63^{\circ} 24.506^{\prime}$ & $20^{\circ} 16.792^{\prime}$ & & 27 & & & 0.44 & \\
\hline $\mathrm{HB}$ & ruderal & $10 \mathrm{Jul}$ & $63^{\circ} 26.911^{\prime}$ & $20^{\circ} 16.250^{\prime}$ & & 30 & & & $\sim 0.5$ & \\
\hline IS & beach & $17 \mathrm{Jul}$ & $63^{\circ} 50.376^{\prime}$ & $21^{\circ} 04.376^{\prime}$ & $8 * 16$ & 51 & 2.06 & & 0.57 & \\
\hline IG & disturbed & $17 \mathrm{Jul}$ & $64^{\circ} 04.963^{\prime}$ & $22^{\circ} 41.548^{\prime}$ & & & & & & \\
\hline
\end{tabular}

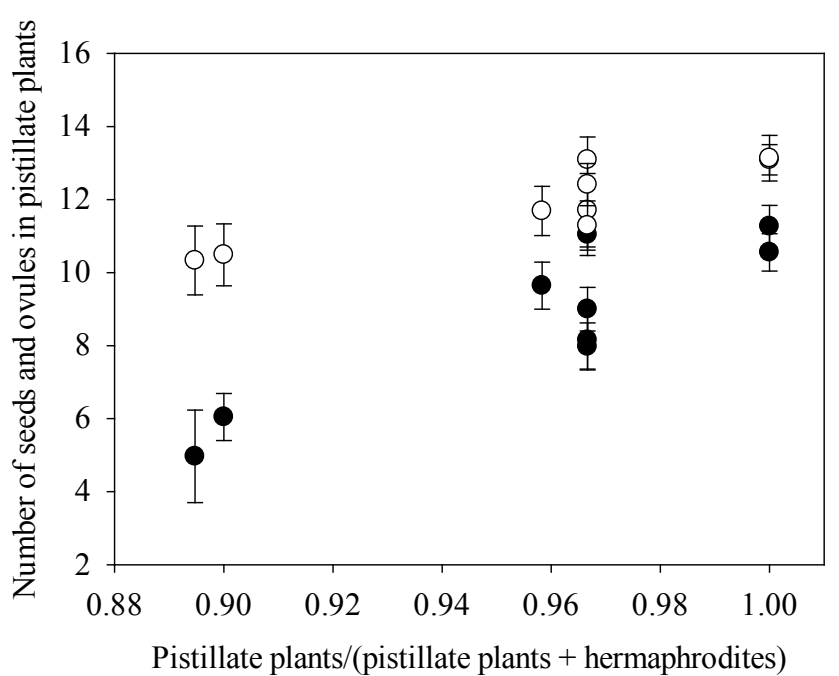

Figure 4. The number of seeds (filled circles) and ovules (open circles) (with error bars, SE) increased as the frequency of pistillate plants increased in relation to the total number of female functioning plants (pistillate + hermaphrodites) in Honckenya peploides.

intermediate and young. At Heimaey and at the mainland, the populations were large and judged to be old (Table 1). The morph ratio was not found to be influenced by the age and disturbance of the population.

\subsection{The number of hermaphrodites}

The number of hermaphrodites was eight plants $(5.9 \%)$ out of the 135 staminate plants sampled at the nine sites. In addition we examined 10 staminate plants on Surtsey from the cohorts from 1973 and 1977 (Cohorts, Table 1), and among those, four carried capsules. In total $8.3 \%$ of the (145) staminate plants were functioning as hermaphrodites at the time when we visited the islands. In the HI populations we sampled 60 staminate plants and $3.3 \%$ produced fruits, whereas we collected capsules from $11.8 \%$ of 85 staminate plants at Surtsey. This difference was non-significant $\left(\chi^{2}\right.$ test, $P=$ 0.097).

\subsection{The mean number of seeds per capsule}

The mean number of seeds per capsule $( \pm \mathrm{SD})$ in 139 sampled pistillate plants was $8.8 \pm 3.12$ and it did not significantly differ between Surtsey and HI ( $t$ test, $p=0.18$; Table 2). The number of ovules in pistillate plants was $11.3 \pm 1.65$, and no difference was found between Surtsey and HI ( $t$ test, $p=0.11$; Table 2). From 13 hermaphrodite individuals in total 25 capsules were sampled. Hermaphrodites had fewer seeds and ovules per capsule than pistillate plants (seeds: $4.9 \pm 2.63$, ovules: $9.4 \pm 2.17, t$ test, $p<0.01$ in both cases). The hermaphroditic plants on Surtsey had the same number of ovules as found in HI ( $t$ test, $p=0.27$; Table 2). The average number of seeds per capsule on Surtsey was, however, 2.7 times the number of seeds per capsule found in hermaphroditic plants on HI, which was a significant difference ( $t$ test, $p=0.026$; Table 2). Note that few capsules from HI were available. The number of seeds and ovules in pistillate plants (functioning as females only) increased as the frequency of pistillate plants increased relative to the total of female functioning plants (pistillate + hermaphroditic plants) (Pearson, $r=0.89, p<0.01$; Fig. 4).

\subsection{Number and size of pollen grains per anther}

Number and size of pollen grains per anther were equal for Surtsey and HI ( $t$ test, $p=0.92$; Table 3 ). The same was the case for number of putative functioning (good) pollen grains ( $t$ test, $p=0.25$ ). The variation within populations was large, ranking from some individuals having no 
good pollen to others having almost all pollen looking good. Hermaphroditic individuals had the same number of pollen grains in total ( $t$ test, $p=0.52)$ and number of good pollen ( $t$ test, $p=0.84$ ) as staminate individuals without capsules (Table 3). We only found two hermaphrodites with suitable (non-dehisced) anthers at the HI sites, therefore no statistics are presented, but the figures can be seen in Table 3. The size of pollen grains was not different among the studied populations and morphs.

\section{Discussion}

Honckenya peploides belongs to the family Caryophyllaceae, where variation in sex expression is frequently found (Desfeux et al., 1996). Populations of H. peploides vary from being gynodioecious (Eithun, 2003; Sánchez-Vilas et al., 2010) to almost dioecious (this study). In gynodioecious mating systems females are often constant in their sex expression whereas hermaphrodites are more plastic, developing seeds in a number reflecting the amount of available resources in form of either pollen delivered or nutrition (Delph, 2003; Delph and Wolf, 2005). In the Arctic such a variation in hermaphrodites has been revealed in Silene acaulis (Alatalo and Molau, 1995; Delph and Carroll, 2001; Philipp et al., 2009; Shykoff, 1988). The variation in seed output from the hermaphrodites in a gynodioecious reproductive system may be the evolutionary route through subdioecy to a dioecious state (Delph, 2003).

Honckenya peploides was first observed on Surtsey with 24 individuals in 1967, and until 1973 the total population size was below 100 plants (Fridriksson, 1992; Jakobsson et al., 2007). This means that the flowering individuals were sparse and scattered and the reproductive system may have changed as a response to these conditions. The first fruiting plant was observed in 1971 (Fridriksson, 1992), suggesting that $H$. peploides on Surtsey needs a juvenile stage of about 4 years before flowering. In Fig. 1 the observed number of individuals is shown for each year from 1967 to 1981. After a stable period from 1967 to 1972 the population size increased 10-fold in 1973. After a new stable period to 1977 a new 10-fold increase occurred from 1977 to 1979. This supports the assumption that the time between generations must be at least 4 years. The maximum number of generations on Surtsey must therefore be about 12 during the 50 years. Many of the plants established in the 1970s are still alive and contribute to the pollen and seed production. Árnason et al. (2014) reported based on investigations of genetic diversity in our material that multiple immigration events have occurred, and it is most likely that immigration by seeds from Heimaey and/or Iceland is still occurring. Consequently, the combination of few generations, longevity of individuals and influx of genes from Iceland and the other Vestmannaeyjar Archipelago islands makes it hard to refer possible changes to evolutionary processes.
In the following, we will discuss alternative explanations of the differences found between samples from Surtsey and those from Heimaey and the south coast of Iceland.

\subsection{Morph ratio}

We found that morph ratios on Surtsey were slightly but significantly biased towards pistillate plants. In all other populations we know of in Greenland, Spain, South Norway, Heimaey, and the undisturbed population at south Iceland, a morph ratio of around 50:50 has been found (Eithun, 2003; Sánchez-Vilas et al., 2010; M. Philipp, personal observations, 2008). In a dimorphic species like H. peploides, intraspecific competition may influence the ratio between morphs. Ecophysiological studies of $H$. peploides had shown morph differences in photosynthetic physiology. Staminate plants had a "higher potential for light acquisition" and allocated more to above-soil surface biomass. Pistillate plants allocated more to below-soil surface biomass and they were more tolerant of water stress (Sánchez-Vilas and Retuerto, 2009; Sánchez-Vilas et al., 2012). H. peploides possesses an extensive network of roots well adapted to exploit the limited nutrients and water that percolate easily in the gravelly substratum (Leblans et al., 2014). Intraspecific competition for soil resources could be strong whereas competition for light may play a minor role, as we rarely observed individuals making interwoven canopies. The regular to random dispersion of individuals suggests that intraspecific competition is strong. Consequently, we should expect on the often very dry substrate on Surtsey that frequency of pistillate plants would increase with the age and density of the population, and that the pistillate plants would be larger than the staminate ones. We did not observe higher pistillate frequency in the older populations, but in the two observed cohorts from 1973 and 1977 the morph ratio was 0.59 and 0.63 , respectively. Furthermore, the minimum distance from a plant to a plant of the same morph should be smaller than to a plant of the different morph. We did not find any coherent pattern. In the only population where we measured the areas of each individual the pistillate plants were larger than the staminate ones. We conclude based on indirect evidence that below-soil surface intraspecific competition occurs and that pistillate plants are larger than staminate ones. The larger sizes may indicate a better survival of pistillate individuals due to higher tolerance to water stress and could probably explain the higher success of the pistillate plants on the gravel covering the island. In addition we showed that females had more ovules and seeds when the frequency of females increased relative to the total number of female functioning plants (pistillate + hermaphrodites). At places where the pistillate plants were dominating, the conditions for them were probably superior to where more hermaphrodites were found. At such places increased allocation to reproduction seems to be an option. 
Table 2. Number of ovules and seeds per capsule in Honckenya peploides on Surtsey and Heimaey + mainland Iceland (HI) ( \pm SD). Number of individuals is included in parentheses.

\begin{tabular}{lcccrr}
\hline & \multicolumn{2}{c}{ Pistillate plants } & & \multicolumn{2}{c}{ Hermaphrodites } \\
\cline { 2 - 3 } \cline { 5 - 6 } & Seed per capsule & Ovules per ovary & & Seed per capsule & Ovules per ovary \\
\hline Surtsey & $8.5 \pm 2.74(87)$ & $11.5 \pm 2.71(87)$ & & $5.7 \pm 1.64(10)$ & $9.0 \pm 3.15(10)$ \\
HI & $9.3 \pm 3.64(52)$ & $12.3 \pm 2.93(52)$ & & $2.1 \pm 2.38(3)$ & $10.6 \pm 1.67(3)$ \\
\hline
\end{tabular}

Table 3. Average number of pollen grains (total) and number of presumed functioning ( $g \circ o d)$ pollen grains per anther $( \pm \mathrm{SD})$. Number of individuals is included in parentheses.

\begin{tabular}{lccccc}
\hline & \multicolumn{2}{c}{ Staminate plants } & & \multicolumn{2}{c}{ Hermaphrodites } \\
\cline { 2 - 3 } \cline { 5 - 6 } Region (N) & No. pollen & No. good pollen & & No. pollen & No. good pollen \\
\hline Surtsey (21) & $1412.7 \pm 391.97(21)$ & $1043.6 \pm 677.08(21)$ & & $1269.0 \pm 317.25(7)$ & $775.4 \pm 579.10(2)$ \\
HI (13) & $1425.9 \pm 437.76(13)$ & $769.6 \pm 654.47(13)$ & & $1414 \pm 50.91(7)$ & $1288 \pm 160.31(2)$ \\
\hline
\end{tabular}

\subsection{Pollen grain number and quality}

We found a large variation among staminate individuals in frequency of putative non-functioning pollen grains. Some individuals had up to $100 \% \mathrm{bad}$ pollen and in the same populations other individuals had $100 \%$ good pollen. This was the case in all populations studied. This means that the plants originating from Iceland already had varying pollen fertility. We expected a higher allocation to pollen in populations with high frequency of pistillate plants (Pannell, 1997). As the pollen grain number and quality did not relate to the frequency of pistillate plants, such change seemed not to have occurred. The varying pollen quality does not seem to influence the present seed quality since we observed a high number of seedlings.

\subsection{Degree of hermaphroditism}

Our second finding was a tendency towards a higher degree of hermaphroditism on Surtsey, especially among the individuals that established in 1973 and 1977 (14.8\%), most likely from locally produced seeds. The higher degree of hermaphroditism has two components: a (weakly significant) higher fraction of staminate plants with capsules on Surtsey $(11.8 \%)$ than on HI $(3.6 \%)$, and a significant higher number of seeds in capsules found on hermaphroditic plants on Surtsey (5.7) compared to the seed per capsule found on hermaphroditic plants on HI (2.1). The tendency to a higher frequency of hermaphrodites on Surtsey than on HI could be a response to low availability of pollen shortly after arrival on the island. At that time, the population size could be counted in tens or hundreds and consequently, the individuals with both female and male function (hermaphrodites) could have had a pronounced advantage by being able to set seeds after selfing. We only found a tendency towards more hermaphrodites on Surtsey compared to HI. This could indicate that the development towards more hermaphroditism on Surtsey did not go far, either due to the longevity of individuals or due to the short period for selection to work. Another aspect working against a further increase of hermaphroditism could be occurrence of geitonogamy in larger clones followed by inbreeding depression (Vallejo-Marin et al., 2010).

Whether pollen transfer has been limited by lack of pollinators is a matter of interest. Ólafsson and Ingimarsdóttir (2009) reported on the immigration of land invertebrates, and as early as 1968 around 70 species were found. In 1971 the species number had increased to 200 . The vast majority of the recorded insects belong to the Diptera, Hymenoptera and Lepidoptera, orders that comprise numerous good pollinators. In spite of the high number of potential pollinators, we saw only the small chironomid Halocladius variabilis in flowers of $H$. peploides (Fig. 3). We suppose that this species was pollinating but due to its small size carried few pollen grains between flowers and may have stayed within clones for several visits. Given the small population size of scattered, flowering $H$. peploides plants until 1972, and given that also at that time $H$. variabilis was the main pollinator, pollen deposition may have been limiting seed set in pistillate plants. In our recent investigation, there were no indications of pollen limitation on fruit and seed set on Surtsey in relation to $\mathrm{HI}$ and further development towards a higher degree of hermaphroditism may not occur. On the contrary, we found that juvenile plant densities were much higher than density of mature plants (Table 1) and we observed numerous seedlings around dried rain pits and streams, sometimes even forming green lines in the landscape (personal observation, 2010). We must conclude that $H$. peploides at present is not limited by insufficient seed set, poor seed dispersal or unfavourable germination conditions. The rapid growth in distribution and abundance on the island gave the same picture. 
Supposing that hermaphrodites had an advantage by being able to set seed after selfing during the early years of colonization by $H$. peploides, the inheritance of the sex distribution becomes important. Subdioecy is often derived from gynodioecy where staminate plants are known to be heterozygous for the sex determination (Lloyd, 1974). Malling (1957) suggested, based on germination of seeds from the three morphs, that the determination of sex in $H$. peploides is male heterogamy. Such a system has been documented in detail in other species belonging to Caryophyllaceae (Westergaard, 1953; Matsunaga and Kawano, 2001). If the above mentioned system is found in H. peploides and if the seeds set by staminate plants (hermaphrodites) are produced mostly by selfing, the offspring would result in a $1: 3$ ratio of pistillate to staminate plants. This could result in an initial increase in the frequency of staminate plants and, most likely, hermaphrodites. We could, on the other hand, consider the male sterility in $H$. peploides to be determined by cytoplasmic inheritance as the occurrence of high frequencies of pistillate plants could indicate (Hermanutz and Innes, 1994). In such a system pistillate plants and hermaphrodites produce pistillate and hermaphrodite plants, respectively. Again, an increase in the fraction of hermaphrodites could be the result.

Accordingly, we suggest that more hermaphrodites were possibly produced in the first generations after colonization, and due to longevity of the individuals this can still be observed and there is no need to postulate evolutionary changes.

The other part of the increased degree of hermaphroditism on Surtsey was the increased seed set in the capsules on hermaphrodites found on Surtsey compared to HI. In general, in our material, the number of ovules and seeds per capsule was lower in hermaphrodites compared to pistillate plants. It has been shown that in the androdioecious Mercurialis аппиа, males produced 5 to 10 times as many pollen grains as hermaphrodites, allocating all available resources into male function (Pannell, 1997). In our material staminate plants carrying capsules did not produce fewer pollen grains per anther than those that did not hold capsules. The lower number of ovules and seeds in capsules on hermaphroditic plants than on plants functioning only as females indicated less allocation to seed set in hermaphrodites, a parallel to the finding in $M$. аппиа. When the few capsules harvested on hermaphrodites were subdivided between Surtsey and HI, the Surtsey capsules included more seeds. This trait is hard to explain without introducing inbreeding depression after geitonogamy, purging of alleles with negative effects, etc. We think our material is too small for further speculations along these lines.

\subsection{Response of the reproductive system}

A subdioecious reproductive system combined with generalist pollinators and clonality is a syndrome often seen (Vallejo-Marín et al., 2010). The expected response to the dispersal of $H$. peploides from the mainland of Iceland to Surtsey, in the direction of more hermaphroditism was, although to a limited extent, found in frequency of hermaphroditic plants as well as in number of seeds per capsule in hermaphrodites. The conflict between sparse mating partners right after the arrival on the island and the subdioecious reproductive system has been solved in favour of the subdioecious reproductive system. Even though hermaphrodites probably had an advantage immediately after colonization, immigrations of insects and longevity of individual plants have ended the response towards an increase in the number of hermaphroditic functioning individuals. The higher seed set in hermaphrodites on Surtsey than in those at the south coast of Iceland including Heimaey adds to this response, but cannot be explained by the knowledge we have got from our limited material. We suggest that the present higher frequency of hermaphroditic plants with a higher seed set per capsule on Surtsey arises from the early situation due to the longevity of individuals. The present surplus of pistillate plants on Surtsey can be explained by the fact that female individuals are more tolerant of the dry substrate found on Surtsey.

\section{The history and future of colonization}

Magnússon et al. $(2009,2014)$ described the plant colonization and succession on Surtsey. Based on the pattern they showed for the development and on our observations, we suggest the following colonization history for $\mathrm{H}$. peploides.

An immigration stage from 1967 to 1972 where probably all plants germinated from seeds from abroad. The population size was about 100, suggesting that the annual input of germinable seeds is around 20. There is no reason to believe that this seed import has changed over the years. There was probably no competition, but pollen and pollinator restriction. Selection for hermaphrodites.

An establishment stage from 1972 to 1978 where the first generation increased the population size 10 -fold. There was no limitation of space, maybe a slight pollinator restriction. Slight selection for hermaphrodites. No competition.

An expansion stage from 1978 to 1982 in which the second generation caused a new 10-fold increase in population size. The increase was probably mainly caused by expansion into previously unoccupied places on Surtsey. There was probably no pollinator restriction (build-up of a local stock of resident insects?) Intraspecific competition may have been active in first colonized areas. No selection for hermaphrodites.

A filling up stage from 1982 to 1990. In this period, H. peploides reached all the areas on Surtsey. There was probably no pollinator restriction, but intraspecific competition began to shape the dispersion of individual within the populations. Slight selection for pistillate plants. 
A community formation stage from 1990 to 2000 . The establishment of the gull colony in the late 1980s resulted in a massive immigration of species, and closed communities began to form (Magnusson et al., 2009, 2014). H. peploides was exposed to both interspecific and intraspecific competition. It was gradually outcompeted in areas with a closed plant cover. Stronger selection for pistillate plants.

An assortative stage from 2000 onwards. Here the total plant species number on Surtsey has stabilized and competitive and late successional species have replaced the pioneers. $H$. peploides is still the dominant plant on most of the island but there is no doubt that it is declining in number. Some of the oldest plants show signs of senescence, and interspecific and intraspecific competition is strong. The pistillate plants that are more efficient may exert competition against staminate plants. Interspecific competition for pollinators may be of importance. In the long run reduced population size and increased distances between individuals may result in renewed selection for hermaphrodites.

The overall conclusion is that the ecological conditions and selective forces change so rapidly on a young volcanic island such as Surtsey that $H$. peploides, with its 4 years' generation time, hardly has had time to respond evolutionarily. Over centuries, it must be assumed that Surtsey will have the same features as the other smaller Vestmannaeyjar Archipelago islands, where $H$. peploides occurs only on a few sandy beaches on the largest island, Heimaey. It will probably go extinct also on Surtsey, when grassy vegetation grows dominant and the sandy beaches are washed away.

Acknowledgements. We especially want to thank Borgthor Magnússon for invitations to participate in the 2010 excursion to Surtsey and the 2013 conference. At our visit on Surtsey we highly appreciated the help, inspiration and guidance from all participants. Erling Ólafsson is thanked for insect identification and Kesara Anamthawat-Jónsson for results from AFLP analyses. We want to express our gratitude to the Surtsey Research Society for logistic support and the Icelandic Coast Guard for transportation. This research was supported by a grant from Carlsberg Foundation (no. 2009010713 ).

Edited by: B. D. Sigurdsson

\section{References}

Alatalo, J. M. and Molau, U.: Effect of altitude on sex ratio in populations of Silene acaulis (Caryophyllaceae), Nord. J. Bot., 15, 251-256, doi:10.1111/j.1756-1051.1995.tb00150.x, 1995.

Árnason, S. H., Thórsson, Æ. Th., Magnússon, B., Philipp, M., Adsersen, H. E., and Anamthawat-Jónsson, K.: Spatial genetic structure of the Sea Sandwort on Surtsey: an immigrant's journey, Biogeosciences Discuss., 11, 10045-10082, doi:10.5194/bgd-11-10045-2014, 2014.
Baker, H. G.: Self-compatibility and establishment after "longdistance" dispersal, Evolution 9, 347-349, doi:10.2307/2405656, 1955.

Barrett, S. C. H.: The evolutionary breakdown of heterostyly, in: The Evolutionary Ecology of Plants, edited by: Bock, J. H. and Linhardt, Y. B. West-view Press, Boulder, Colorado, USA, 151171, 1989.

Böcher, T. W., Fredskild, B., Holmen, K., and Jakobsen, K.: Grønlands Flora. P. Haase \& sons Forlag, København, 1978.

Bramow, C., Hartvig, I., Larsen, S. B., and Philipp, M.: How a heterostylous plant species responds to life on remote islands: a compative study of the morphology and reproductive biology of Waltheria ovata on the coasts of Ecuador and the Galápagos Islands, Evol. Ecol., 27, 83-100, doi:10.1007/s10682-012-9588-9, 2013.

Delph, L. F.: Sexual dimorphism in gender plasticity and its consequences for breeding system evolution, Evol. Develop., 5, 34-39, doi:10.1046/j.1525-142X.2003.03006.x, 2003.

Delph, L. F. and Carroll, S. B.: Factors affecting relative seed fitness and female frequency in a gynodioecious species, Silene acaulis, Evol. Ecol. Res., 3, 487-505, 2001.

Delph, L. F. and Wolf, D. E.: Evolutionary consequences of gender plasticity in genetically dimorphic breeding systems, New Phytol., 166, 119-128, doi:10.1111/j.1469-8137.2005.01339.x, 2005.

Desfeux, C., Maurice, S., Henry, J.-P., Lejeune, B., and Gouyon, P.H.: Evolution of reproductive systems in the genus Silene, P. Roy. Soc. Lond. B-Bio., 263, 409-414, doi:10.1098/rspb.1996.0062, 1996.

Eithun, A.: Reproduction, genetic variation and responses to temperature increase in populations of Honkenya peploides (L.) Ehrh. in W Greenland, Svalbard and S Norway, M.S. thesis, University of Oslo, 2003.

Fridriksson, S.: Vascular plants on Surtsey 1971-1976, Surtsey Research Progress Report VIII, 9-24, 1978.

Fridriksson, S.: Vascular plants on Surtsey 1977-1980, Surtsey Research Progress Report IX, 46-58, 1982.

Fridriksson, S.: The volcanic island of Surtsey, Iceland, a quartercentury after it "rose from the sea", Environ. Conserv., 16, 157$162,1989$.

Fridriksson, S.: Vascular plants on Surtsey 1981-1990, Surtsey Research Progress Report X, 17-30, 1992.

Fridriksson, S.: Vascular plants on Surtsey, Surtsey Research Progress Report 11, 21-28, 2000.

Fridriksson, S. and Johnsen, B.: The colonization of vascular plants on Surtsey in 1967, Surtsey Research Progress Report IV, 43-49, 1968.

Hermanutz, L. A. and Innes, D. J.: Gender variation in Silene acaulis (Caryophyllaceae), Plant Syst. Evol., 191, 69-81, doi:10.1007/BF00985343, 1994.

Jakobsson, S. P., Magnússon, B., Ólafsson, E., Thorvardardóttir, G., Gunnarsson, K., Baldursson, S., and Petersen, Ae.: Nomination of Surtsey for the UNESCO World Heritage List, edited by: Baldursson, S. and Ingadóttir, Á., Icelandic Institute of Natural History, 123 pp., 2007.

Leblans, N. I. W., Sigurdsson, B. D., Roefs, P., Thuys, R., Magnússon, B., and Janssens, I. A.: Effects of seabird nitrogen input on biomass and carbon accumulation after 50 years of primary 
succession on a young volcanic island, Surtsey, Biogeosciences Discuss., 11, 6269-6302, doi:10.5194/bgd-11-6269-2014, 2014.

Lloyd, D. G.: Theoretical sex ratios of dioecious and gynodioecious angiosperms, Heredity, 32, 11-34, doi:10.1038/hdy.1974.2, 1974.

Magnússon, B., Magnússon, S. H., and Fridriksson, S.: Developments in plant colonization and succession on Surtsey during 1999-2008, Surtsey Res., 12, 57-76, 2009.

Magnússon, B., Magnússon, S. H., Ólafsson, E., and Sigurdsson, B. D.: Plant colonization, succession and ecosystem development on Surtsey with reference to neighbouring islands, Biogeosciences, 11, 5521-5537, doi:10.5194/bg-11-5521-2014, 2014.

Malling, H.: The chromosome number of Honckenya peploides (L.) Ehrh., with a note on its mode of sex determination, Hereditas, 43, 517-524, doi:10.1111/j.1601-5223.1957.tb03454.x, 1957.

Matsunaga, S. and Kawano, S.: Sex determination by sex chromosomes in dioecious plants, Plant Biol., 3, 481-488, doi:10.1055/s-2001-17735, 2001.

Ólafsson, E. and Ingimarsdóttir, M.: The land-invertebrate fauna on Surtsey during 2002-2006, Surtsey Res., 12, 113-128, 2009.

Pannell, J. R.: Variation in sex ratios and sex allocation in androdioecious Mercurialis annua, J. Ecol., 85, 57-69, doi:10.2307/2960627, 1997.

Philipp, M., Böcher, J., Siegismund, H. R., and Nielsen, L. R.: Structure of a plant-pollinator network on a pahoehoe lava desert of the Galápagos Islands, Ecography, 29, 531-540, doi:10.1111/j.0906-7590.2006.04546.x, 2006.

Philipp, M., Jakobsen, R. B., and Nachman, G.: A comparison of the pollen-siring ability and life history between females and hermaphrodites of subdioecious Silene acaulis, Evol. Ecol. Res., 11, 787-801, 2009.
Sánchez-Vilas, J. and Retuerto, R.: Sex-specific physiological, allocation and growth responses to water availability in the subdioecious plant Honckenya peploides, Plant Biol., 11, 243-254, doi:10.1111/j.1438-8677.2008.00105.x, 2009.

Sánchez-Vilas, J., Philipp, M., and Retuerto, R.: Unexpectedly high genetic variation in large unisexual clumps of the subdioecious plant Honckenya peploides (Caryophyllaceae), Plant Biol., 12, 518-525, doi:10.1111/j.1438-8677.2009.00231.x, 2010.

Sánchez-Vilas, J., Bermúdez, R., and Retuerto, R.: Soil water content and patterns of allocation to below- and aboveground biomass in the sexes of the subdioecious plant Honckenya peploides, Ann. Bot. London, 110, 839-849, doi:10.1093/aob/mcs157, 2012.

Shykoff, J. A.: Maintenance of gynodioecy in Silene acaulis (Caryophyllaceae): stage-specific fecundity and viability selection, Am. J. Bot., 75, 844-850, doi:10.2307/2444003, 1988.

Tsukui, T. and Sugawara, T.: Dioecy in Honckenya peploides var. major (Caryophyllaceae), Bot. Mag. Tokyo, 105, 615-624, 1992.

Vallejo-Marín, M., Dorken, M. E., and Barrett, S. C. H.: The ecological and evolutionary consequences of clonality for plant mating, Annu. Rev. Ecol. Evol. S, 41, 193-213, doi:10.1146/annurev.ecolsys.110308.120258, 2010.

Westergaard, M.: Über den Mechanismus der Geschlechtsbestimmung bei Melandrium album, Naturwissenschaften, 40, 253360, doi:10.1007/BF00590417, 1953. 